\title{
Effect of Climatic Conditions on Treatment Efficiency of Wastewater Stabilization Ponds at Chokera, Faisalabad
}

\author{
Hafiz Qasim Ali ${ }^{1 \mathrm{a}}$, Amir Farooq ${ }^{1 \mathrm{~b}}$, Muzaffar Ahmad ${ }^{1 \mathrm{c}}$, Mohammad Laeeque Ahmed ${ }^{1 \mathrm{~d}}$, \\ Muhammad Akhtar'1e
}

RECEIVED ON 06.03.2018, ACCEPTED ON 17.08.2018

\begin{abstract}
Wastewater management is one of the biggest challenges in the world due to increase in population and industrialization. In Faisalabad (FSD), wastewater treatment is being done through Wastewater Stabilization Ponds (WSPs) at Chokera, which is one of the most economical methods of Wastewater Treatment (WWT). Various parameters were examined to check wastewater treatment efficiency of the ponds under diverse climatic conditions. These included Biochemical Oxygen Demand (BOD), pH, Chemical Oxygen Demand (COD), Turbidity, Copper, Total Solids (TS), Total Dissolved Solids (TDS) and Lead. Six locations which were selected for monitoring treatment efficiency, included inlet and outlet of treatment plant, influent of anaerobic ponds, effluent of anaerobic ponds, effluent of facultative ponds, and Pharang drain before and after blending with treated sewage. The testing was performed in two seasons (i.e. Winter 2015 and Summer 2016) in Environmental Engineering Laboratory, Department of Civil Engineering, The University of Lahore, Pakistan. BOD $_{5}$ removal efficiency of the treatment plant was found $30.08 \%$ in winter and $51.74 \%$ in summer against designed value of $90 \%$ removal. Most of the parameters of the effluent were not meeting the Punjab Environmental Quality Standards (PEQS). The reasons of low efficiency are; variation in climatic conditions (i.e. less solar heat intensity, wind speed and ceased microbial activity in winter), lack of funds by government, increased population, mixing of industrial sewage with domestic sewage and less attention being paid to maintain the performance of Ponds. The study was carried out to assess and compare the efficiency of treatment plant with PEQS in two climatic conditions.
\end{abstract}

Keywords: Comparison, Wastewater Stabilization Ponds, Treatment Plant, Efficiency, Faisalabad.

\section{INTRODUCTION}

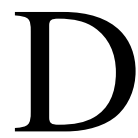
isposal of poorly treated and untreated industrial/domestic wastewater has threatened the quality of surface water bodies in developing countries worldwide. Aquatic ecosystem is being deteriorated by the disposal of untreated wastewater, which causes health hazards to its ultimate user [1]. Various investigations reports that water pollution has increased in Pakistan. The pollution levels are significantly higher in metropolitan cities due to the presence of number of industries. According to census, the population is expected to rise up to 221 million in 2025 [2]. In the past, Pakistan was considered as one of the water surplus country but now the per capita availability of water has decreased from $5600-1000 \mathrm{~m}^{3}$ and it is estimated to drop by $700 \mathrm{~m}^{3}$ in 2025 [2, 3]. A report revealed that in 2017 approximately $60 \%$ of urban wastewater was produced by 10 major cities of Pakistan from which less than $8 \%$ was treated and rest of the water was discharged in Rivers. This water comprising of hazardous metals was later exploited for irrigation purposes due to which all these

\footnotetext{
${ }^{1}$ Department of Civil Engineering, The University of Lahore, Lahore, Pakistan. Email: ${ }^{\mathrm{a} q a}$ asim.ali@ce.uol.edu.pk (Corresponding Author), ${ }^{\text {bamirepapb@yahoo.com, }}$ cmuzaffar.ahmad@ce.uol.edu.pk, dlaeeque.ahmad@ce.uol.edu.pk, eakhtarali.ce@gmail.com

This is an open access article published by Mehran University of Engineering and Technology, Jamshoro under CC BY 4.0 International License.
} 
contaminations transferred into vegetables. This fact is considered as the biggest reason for fatal diseases in Pakistan. Study also revealed that most of the cities of Pakistan lack wastewater treatment plants as well. Only $0.01 \%$ wastewater in Lahore, $25.6 \%$ in Faisalabad, $15.9 \%$ in Karachi, 34\% in Hyderabad and $36.2 \%$ in Peshawar is being treated [4]. To minimize its effects and reuse of treated wastewater, it is needed to install treatment plants.

WSPs due to their simplicity in function, less use of mechanical equipment and little need of maintenance are considered as the best option in developing countries like Pakistan [5]. WSPs are being used all over the world for wastewater treatment, particularly in developing countries and small towns. High algal concentration in the effluent is the main obstacle for this type of treatment [6]. This paper aims at achieving the listed objectives; to monitor the treatment efficiency of Wastewater Treatment Plant (WWTP) in Faisalabad vis-à-vis compliance of PEQS and to identify the factors affecting the efficiency of the WWTP.

\section{ATERIALS AND METHOD}

Treatment plant under consideration was designed to treat $20 \mathrm{MG}$ of domestic wastewater in a day. The treatment system consists of 4 Sludge drying ponds, 6 anaerobic ponds and 6 facultative ponds. These ponds cover 5, 25 and 125 hectares, respectively. Fig. 1 shows the layout of treatment plant along with sampling points. The treated wastewater from treatment plant is discharged into Pharang drain that ultimately disposed into river Chenab. Wastewater samples were collected in two seasons; winter 2015 and summer 2016 from six locations. Samples were drawn based on detention time of the ponds. Sampling in winter season was done during the months of December and January 2015. While in summer season it was done during the months of June and July 2016. Sampling in two different seasons was done to assess the climatic effect on treatment efficiency of the ponds. To make composite sample, grab samples were taken with four hours interval. Temperature, $\mathrm{pH}$, and turbidity of the samples were measured in the field. Environmental Engineering Laboratory of The
University of Lahore was used for analysis of collected wastewater samples from WWTP in FSD. Following parameters were measured in the Lab:

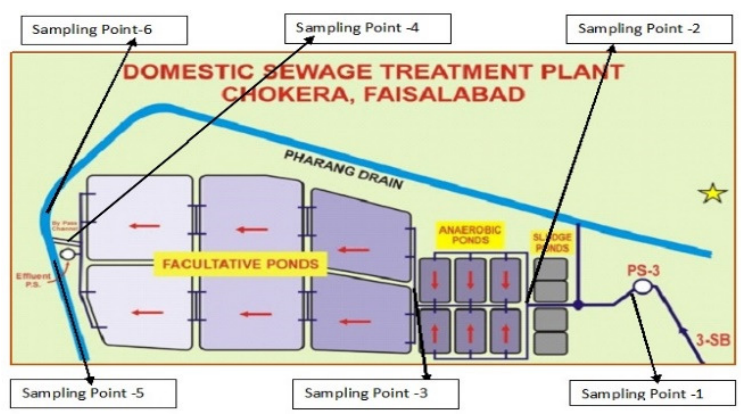

Fig. 1: Layout of Sewage Treatment Plant with Sampling Locations

Biochemical Oxygen Demand (BOD5): The chemical reagents used for dilution media were, $\mathrm{CaCl}_{2}$ (Calcium Chloride) solution, $\mathrm{FeCl}_{3}$ (Ferric Chloride) solution, $\mathrm{MgSO}_{4}$ (Magnesium Sulfate) solution and readily available Phosphate Buffer solution. For 1 liter dilution media, $1 \mathrm{~mL}$ of each reagent and buffer solution were added and then mixture was aerated for 30-45 minutes to increase the dissolved oxygen in dilution media. Sampling bottles were divided into four groups, where each group contained different amount of wastewater sample for dilution. Group 1: contained $1 \mathrm{~mL}$ wastewater sample in each of the three $A_{1}, A_{2}$, and $A_{3}$ labeled bottles. Group 2: contained 3 $\mathrm{mL}$ wastewater sample in each of the three $\mathrm{B}_{1}, \mathrm{~B}_{2}$, and $\mathrm{B}_{3}$ labeled bottles. Group 3: contained $5 \mathrm{~mL}$ wastewater sample in each of the three $\mathrm{C}_{1}, \mathrm{C}_{2}$, and $\mathrm{C}_{3}$ labeled bottles, and in Group 4: two bottles labeled blank $1\left(\mathrm{Bl}_{1}\right)$ and blank $2\left(\mathrm{Bl}_{2}\right)$ were filled with dilution media only. During the addition of wastewater samples, first bottles were filled half with dilution media. Then after adding the required quantities (as mentioned above) of wastewater samples, all the bottles were filled to the brim with dilution media and then capped with water seal on cap of the BOD bottles to stop the variation of dissolved oxygen.

Labelled 1 bottles from each group (A1, B1, C1 and B11) were tested on day 1 to check the initial dissolved oxygen. After which labelled 2 and 3 bottles from each group were placed in the incubator (SUPICO incubator with $110 \mathrm{~L}$ capacity) at $20 \pm 2^{\circ} \mathrm{C}$. Labelled 2 bottles $\left(A_{2}, B_{2}\right.$ and $\left.C_{2}\right)$ were tested using DO 
(Dissolved Oxygen) meter after 2 days to check whether the dissolved oxygen is above $2 \mathrm{mg} / \mathrm{l}$ in each set is available or not, and labelled 3 bottles $\left(A_{3}, B_{3}\right.$, $\mathrm{C}_{3}$ and $\mathrm{Bl}_{2}$ ) were tested on fifth day of the experiment. Afterwards $\mathrm{BOD}_{5}$ was calculated using formulae given in Equation (1).

$$
\begin{aligned}
\mathrm{BOD}_{5\left(\frac{\mathrm{mg}}{\mathrm{l}}\right)}=\frac{\left(\mathrm{A}_{1}-\mathrm{A}_{3}\right)-\left(\mathrm{Bl}_{1}-\mathrm{Bl}_{2}\right)}{\text { Volume of Sample }} \\
\quad \times \text { vol. of BOD botlle }(300 \mathrm{ml})
\end{aligned}
$$

where,

$\mathrm{A}_{1}=$ First day reading

$\mathrm{A}_{3}=$ Five-day reading

$\mathrm{Bl}_{1}-\mathrm{Bl}_{2}=$ Blank Correction of first and fifth day

Chemical Oxygen Demand (COD): Readings were taken using NOVA 60 equipment. Adjustment of thermo-reactor (SPECTROQUANT ${ }^{\mathrm{M}}$ TR-320) was done according to test specifications (i.e. Temperature $148^{\circ} \mathrm{C}$ for two hours). Test kits were cooled in air for 10 minutes before taking the reading using NOVA 60 .

pH and Temperature: Readings were noted using $\mathrm{pH}$ meter (EUTECH Instruments $\mathrm{pH} 510 \mathrm{pH} / \mathrm{mV} /{ }^{\circ} \mathrm{C}$ ). Before testing, $\mathrm{pH}$ meter was calibrated using 7, 10 and $4 \mathrm{pH}$ buffer solutions. To insure accurate readings of $\mathrm{pH}$ and temperature $\mathrm{pH}$ meter probe and thermometer probe were left in sample for almost 5 to 10 minutes.

Turbidity: Turbidity meter (EUTECH Instruments Turbidimeter TN-100) was used for turbidly measurement. After calibration of the meter with standard solution, turbidity cell was filled with the sample and then placed inside meter. Care was taken before placing the cell in meter that the cell has its outside surface properly cleaned and lines of cell and turbidity meter are parallel to each other. Then measured values of turbidly were recorded.

Total Solids (TS): Took a pre-weighed china dish and assumed its weight as $\mathrm{W}_{1}$ in grams. Then added well shaken $100 \mathrm{~mL}$ sample in that china dish and placed it on a steam bath to evaporate the sample. To further achieve complete dryness dish along with sample were placed in oven at $103-105^{\circ} \mathrm{C}$ for 24 hours. After that it was placed in desiccators to cool down and then weighed as $\mathrm{W}_{2}$ in grams. Total solids (TS) are measured using formula in equation 2 .

$\operatorname{TS}(\mathrm{mg} / \mathrm{l})=\left(\mathrm{W}_{2}-\mathrm{W}_{1}\right) \times 10^{6} / \mathrm{ml}$ of sample

Total Dissolved Solids (TDS): Took filter paper and supposed its weight as $\mathrm{W}_{5}$ in grams. $100 \mathrm{~mL}$ well shaken sample was filtered using vacuum filtration technique. Insoluble residue is left on filter paper, while soluble filtrate is transferred in pre-weighed china dish. China dish weight was supposed as $\mathrm{W}_{3}$ in grams. And weight of china dish along with filtrate is taken as W4 in grams. Total dissolved solids (TDS) were measured using formula in equation (3).

$\operatorname{TDS}(\mathrm{mg} / \mathrm{l})=\left(\mathrm{W}_{4}-\mathrm{W}_{3}\right) \times 10^{6} / \mathrm{ml}$ of sample

Total Suspended Solids (TSS): Now transferred the filter paper along with residue into the oven for complete dryness. Then weighed the filter paper as $\mathrm{W}_{6}$ (weight of suspended solids + weight of filter paper) in grams. Total suspended solids (TSS) were measured using formula in equation (4).

$\operatorname{TSS}(\mathrm{mg} / \mathrm{l})=\left(\mathrm{W}_{6}-\mathrm{W}_{5}\right) \times 10^{6} / \mathrm{ml}$ of sample

Samples were drawn from influent of treatment plant (i.e. before screening), influent of anaerobic ponds (i.e. after screening), effluent of anaerobic ponds, effluent of facultative ponds, drain before mixing of treated effluent and drain after mixing with treated effluent. All Samples were drawn, transported, and examined as prescribed in standard methods for the examination of water and wastewater [7]. The air temperatures measured at the site were 10.4 and $24.4^{\circ} \mathrm{C}$ in winter 2015 and summer 2016 seasons respectively, which were within the desired limits. The temperature of final effluent was complying with the PEQS and World Health Organization (WHO) guidelines that may not have any effect on the receiving water bodies [8].

\section{RESULTS AND DISCUSSION}

\subsection{Physiochemical Quality of Wastewater Sample Drawn from WSPs and Pharang Drain}


Table1 shows the results of physiochemical parameters of samples taken from selected locations. Generally, the WWT facilities provided at Chokera WWTP although brought down the concentration of various pollutants but this decrease was not significant. The WWTP decreased the turbidity from $255 \mathrm{NTU}$ and 227 to $45.9 \mathrm{NTU}$ and 57.2 NTU in summer 2015 and winter 2016 seasons correspondingly.

The elimination of turbidity was not meeting the prescribed limit i.e. $\square \square 5 \mathrm{NTU}$, as required vide PEQS. The values of TS, TDS and TSS (Total Suspended Solids) achieved after secondary treatment in summer were 2642.5, 1884 and $28 \mathrm{mg} / \mathrm{l}$ respectively. On the other hand, in winter values were 2984, 2317.5 and $34 \mathrm{mg} / \mathrm{l}$ correspondingly. High value of TDS can cause toxicity to freshwater animals by initiating the osmotic stress that ultimately leads to the disturbance of osmoregulatory capability of microorganisms [9]. Higher value of TSS at inlet of treatment plant can cause greater accumulation of sludge in WSPs which reduce the capacity of ponds more rapidly [10]. However, present study revealed that the concentration of TSS was lower than given limits.

In chemical parameters, decrease was also observed as in physical parameters. In summer season values of $\mathrm{BOD}_{5}$ after treatment reduced from 425.7-200.6 mg/1 and in winter season from 525.13-360.16 mg/l. The removal efficiency of $\mathrm{BOD}_{5}$ in summer was $52.88 \%$ and in winter it was $31.42 \%$. Removal efficiency in both seasons was not meeting the designed $90 \%$ removal efficiency. COD values observed in summer season decreased from 710-303 $\mathrm{mg} / \mathrm{l}$ in untreated wastewater and treated effluent, respectively. In winter season it decreased from 990-428 mg/l which are above the required limits. Ups and downs were observed in the $\mathrm{pH}$ values, but these were within the neutral range.

In wastewater treatment, through oxidation ponds, methanogens and acidogenesis cause the changes in $\mathrm{pH}$ of sewage. Methanogens process controls the $\mathrm{pH}$ within neutral range and acidogenesis causes the drop in $\mathrm{pH}$ due to growth of fatty acids [10-12] also reported the neutral range of $\mathrm{pH}$.

DO is essential for sustaining biological life in aquatic system [13] however, DO level in this study was determined in the form of $\mathrm{BOD}_{5}$ and $\mathrm{COD}$. Results showed that the DO was very less as the values of $\mathrm{BOD}_{5}$ and $\mathrm{COD}$ were found above the prescribed limits of [14].

\subsection{Efficiency of Anaerobic Ponds}

Efficiency of anaerobic ponds against various parameters is given in Table 1. Generally, there was decrease in the values of all parameters after leaving naerobic ponds but slight increase was observed in temperature. More than 50\% removal occurred in TSS and VSS after passing through anaerobic ponds during both seasons. Change occurred in $\mathrm{pH}$ and removal of TS observed through anaerobic treatment in both seasons were very low (Fig. 2).

\begin{tabular}{|c|c|c|c|c|c|c|c|c|c|c|c|}
\hline \multicolumn{12}{|c|}{ Table 1: Physio-Chemical Characteristics of Wastewater Samples and their Removal Efficiency } \\
\hline$\dot{\check{z}}$ & 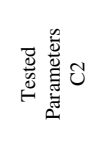 & 苞 & 总 营 & 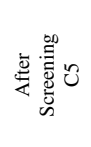 & o & 总离 & 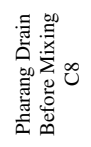 & 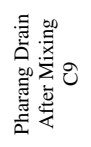 & 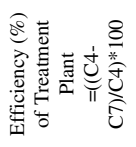 & 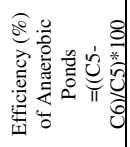 & 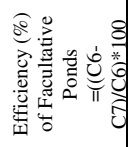 \\
\hline \multirow{2}{*}{1} & \multirow{2}{*}{$\begin{array}{l}\mathrm{BOD}_{5} \\
(\mathrm{ppm})\end{array}$} & Summer & 425.69 & 420.51 & 398 & 200.6 & 376 & 295.6 & 52.88 & 5.35 & 49.60 \\
\hline & & Winter & 525.13 & 520.66 & 418.4 & 360.16 & 472 & 395.6 & 31.42 & 19.64 & 13.92 \\
\hline \multirow{2}{*}{2} & \multirow{2}{*}{$\begin{array}{l}\mathrm{COD} \\
(\mathrm{ppm})\end{array}$} & Summer & 710 & 543 & 395 & 303 & 396 & 379 & 57.32 & 27.26 & 23.29 \\
\hline & & Winter & 990 & 682 & 426 & 428 & 414 & 424 & 56.77 & 37.54 & -0.47 \\
\hline \multirow[b]{2}{*}{3} & \multirow{2}{*}{$\begin{array}{c}\mathrm{pH} \\
\text { (H+ } \\
\text { ions) }\end{array}$} & Summer & 7.95 & 6.9 & 6.78 & 7.78 & 6.3 & 7.83 & 2.14 & 1.74 & -14.75 \\
\hline & & Winter & 7.85 & 7.7 & 7.4 & 7.58 & 6.23 & 7.19 & 3.44 & 3.90 & -2.43 \\
\hline \multirow{2}{*}{4} & \multirow{2}{*}{$\begin{array}{l}\text { Turbidity } \\
\text { (NTU) }\end{array}$} & Summer & 255 & 242 & 219.6 & 45.9 & 236 & 132.3 & 82.00 & 9.26 & 79.10 \\
\hline & & Winter & 227 & 222 & 163 & 57.2 & 224 & 163.8 & 74.80 & 26.58 & 64.91 \\
\hline \multirow{2}{*}{5} & \multirow{2}{*}{$\begin{array}{c}\text { TS } \\
(\mathrm{ppm})\end{array}$} & Summer & 3816 & 3688 & 3620 & 2642.5 & 2220 & 2417 & 30.75 & 1.84 & 27.00 \\
\hline & & Winter & 3847 & 3543 & 3356 & 2984 & 2356 & 2754 & 22.43 & 5.28 & 11.08 \\
\hline \multirow{2}{*}{6} & \multirow{2}{*}{$\begin{array}{c}\text { TDS } \\
\text { (ppm) }\end{array}$} & Summer & 3097 & 2684 & 2108 & 1884 & 1257.9 & 1725 & 39.17 & 21.46 & 10.63 \\
\hline & & Winter & 3330 & 2848 & 2462.5 & 2317.5 & 1757.5 & 2022.5 & 30.41 & 13.54 & 5.89 \\
\hline \multirow[b]{2}{*}{7} & \multirow{2}{*}{$\begin{array}{c}\text { TSS } \\
(\mathrm{ppm})\end{array}$} & Summer & 416 & 310 & 98 & 28 & 136 & 42 & 93.27 & 68.39 & 71.43 \\
\hline & & Winter & 442 & 290 & 82 & 34 & 116 & 44 & 92.31 & 71.72 & 58.54 \\
\hline
\end{tabular}

Mehran University Research Journal of Engineering and Technology, Vol. 40, No. 1, January 2021 [p-ISSN: 0254-7821, e-ISSN: 2413-7219] 


\subsection{Efficiency of Facultative Ponds}

Table 1 represents the efficiency of WSPs and treatment plant. The results show that efficiency of facultative ponds was better than anaerobic ponds. The trend of the treatment against each parameter was same as in anaerobic ponds (Fig. 3).

\subsection{Efficiency of Treatment Plant}

Table1 represents the efficiency of treatment plant. In both seasons, it was observed that TSS removal efficiency was above $90 \%$ and turbidity removal efficiency was about $80 \%$. 50-60\% removal efficiency was achieved in $\mathrm{BOD}_{5}$ and $\mathrm{COD}$. However, in winter season $\mathrm{BOD}_{5}$ removed was less than $50 \%$. TS, TDS and $\mathrm{pH}$ removed below $50 \%$ in both seasons (Fig. 4). Generally, [15] reported that, there are several causes for deterioration of the purification performance; such as unsuitable design of the pond; incomplete mixing of aerated pond; type of preliminary treatment; insufficient maintenance and increased organic influent loads.

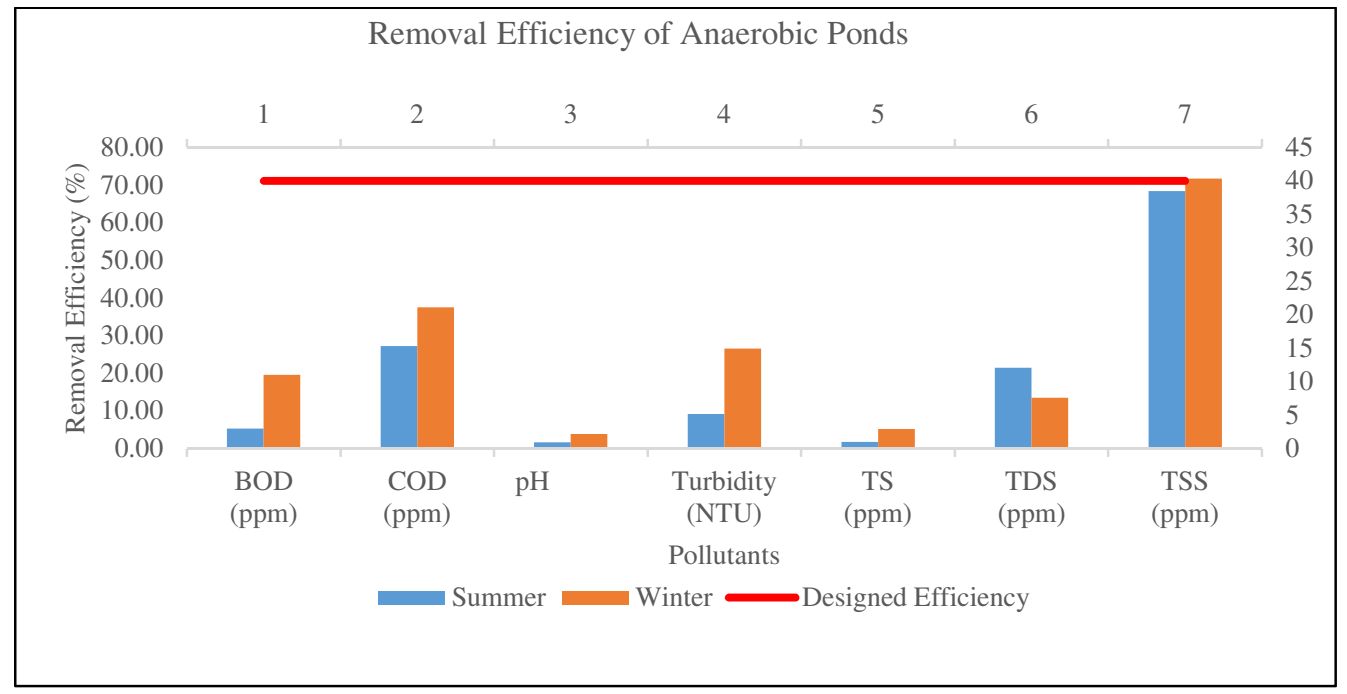

Fig. 2: Removal Efficiency of Anaerobic Ponds in Removing Selected Parameters

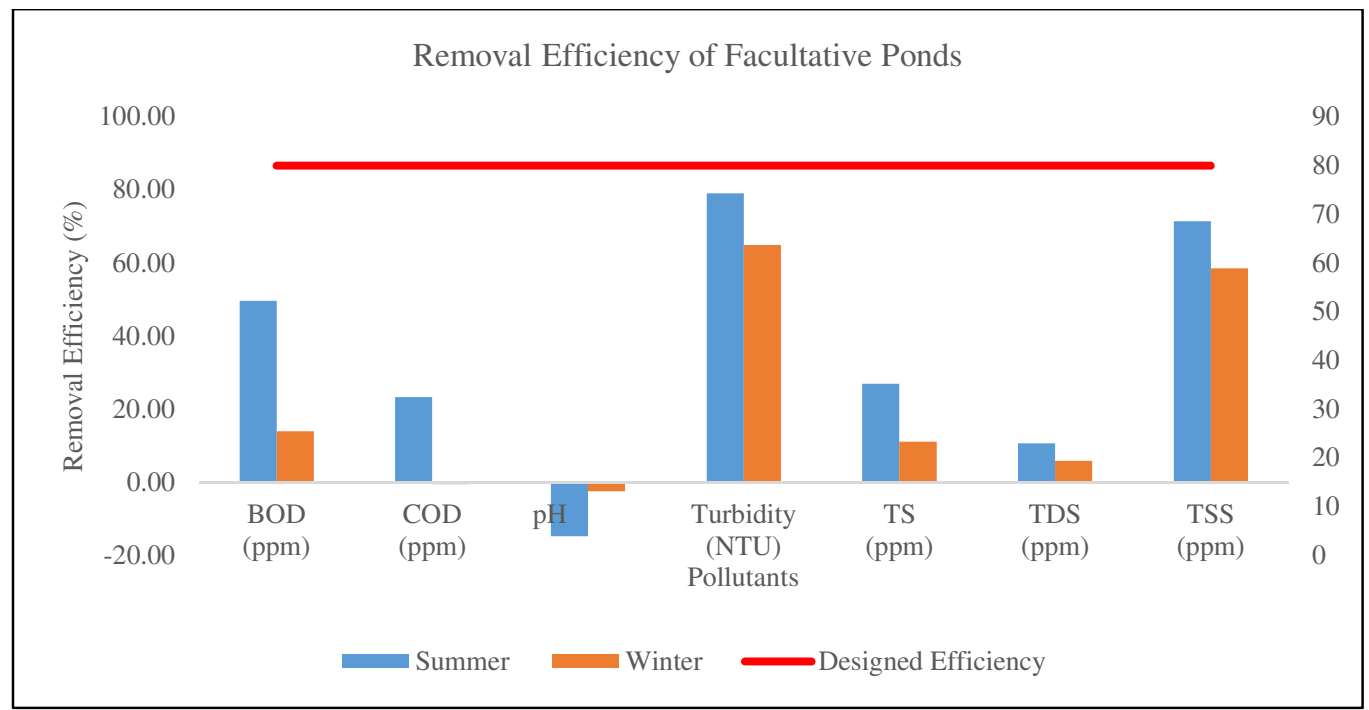

Fig. 3: Removal Efficiency of Facultative Ponds in Removing Selected Parameters 


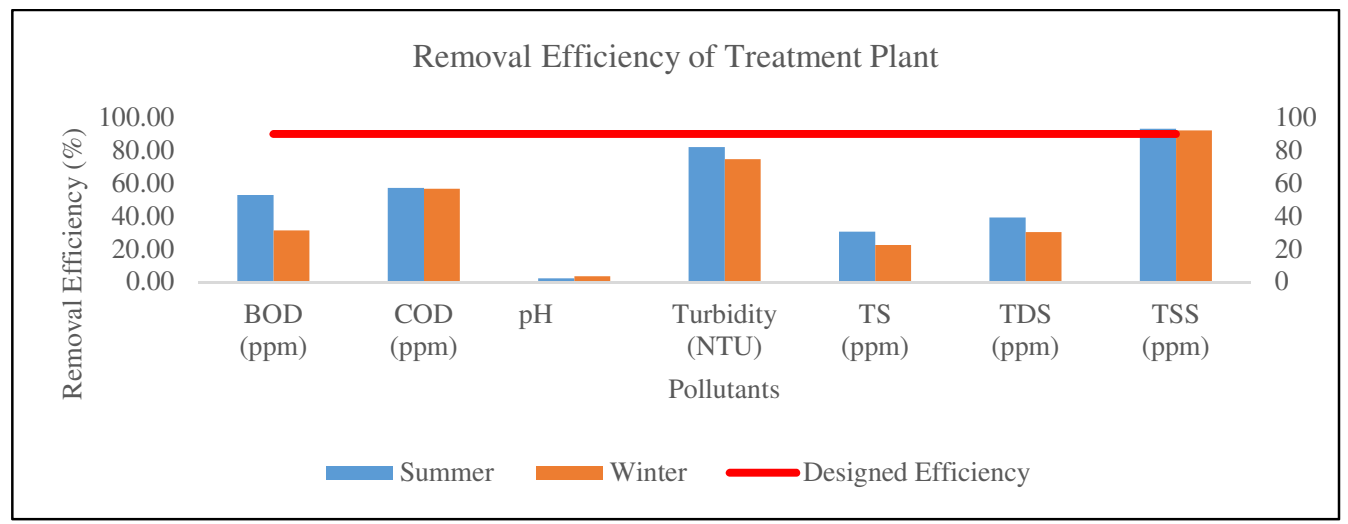

Fig. 4: Removal Efficiency of Treatment Plant in Removing Selected Parameters

\subsection{Comparison of Treated Wastewater with PEQS Permissible Limits}

Table1 shows, in summer value of $\mathrm{BOD}_{5}$ after treatment reduced from 425.7 to $200.6 \mathrm{mg} / \mathrm{l}$ and in winter from 525.13 to $360.16 \mathrm{mg} / \mathrm{l}$. The removal efficiency of $\mathrm{BOD}_{5}$ in summer was $52.88 \%$ and in winter $31.42 \%$. Removal efficiency in both seasons was not within the prescribed limits as given in PEQS. The prescribed upper limit of $\mathrm{BOD}_{5}$ as given in PEQS is $40 \mathrm{mg} / \mathrm{l}$. The experimental values of COD were found 303 and $428 \mathrm{mg} / \mathrm{l}$ against permissible limit of $150 \mathrm{mg} / \mathrm{l}$ which are above the limits and the probable reasons for these above values may include growth of weeds, decay of Algae and industrial discharges.

The prescribed limit as given in PEQS of TDS and TSS are 3500 and $150 \mathrm{mg} / \mathrm{l}$ correspondingly. However, the experimental values were above the given standards in both seasons (i.e. winter 2015 and summer 2016).

\subsection{Effect of Treated Wastewater on the Quality of Water in Drain}

Pharang drain which carries the domestic effluent as well as some industrial untreated discharges ultimately flows into the Chenab River [16]. Parameters which were considered in the study of treatment plant showed positive impact on Pharang drain however, this positive impact was not significant. Water quality in the drain does not comply with the PEQS so this contaminated water is not suitable for agriculture. The unlined drain also has potential to negatively impact the ground water quality in the vicinity.

\section{CONCLUSIONS}

The results of this study show that ambient temperature affects the treatment efficiency of wastewater stabilization ponds. The treated effluent from treatment plant does not comply with PEQS and it is not suitable for irrigation purpose. Treatment plant at Chokera needs proper measures to be taken, to improve its treatment efficiency so that it can meet the PEQS. Waste water is affecting water bodies as well as ground water, so when it is treated we can save our water resources from contamination and dumping of it into water bodies will be free of environmental health hazards.

\section{ACKNOWLEDGMENTS}

The authors expresses their deepest thanks to Mr. Abdul Ghaffar Naveed, Deputy Director, P\&D WASA, Faisalabad and Prof. Dr. Muhammad Zulfiqar Ali Khan, Department of Civil Engineering, The University of Lahore, Lahore, Pakistan, for their great help in doing sampling from Chokera wastewater treatment plant, Faisalabad and accomplishing the laboratory tests in environmental engineering laboratory of civil engineering department provided in this research work.

\section{REFERENCES}

[1] Aloo B.N, "Towards Embracing Sewage Stabilization Ponds for Sewage Effluent Treatment for Small Communities", International Research Journal of 
Environment Sciences, Vol. 4, No. 5, pp. 9195, May, 2015.

[2] Bhatti Z.A., Qaiser M., Raja I.A., Malik A.H., Rashid N., Khan Z.M., Maqbool F., "Low Cost Muncipal Wastewater Treatement Options for use in Pakistan-A Review", Science Vision, Vol. 15, No.1, pp. 71-78, 2009.

[3] Murtaza G., Zia H.H., "Wastewater Production, Treatement and Use in Pakistan", Proceedings of the Second Regional Workshop of the Project Safe Use of Waste Water in Agricultue, pp. 16-18, 2012.

[4] Wasif, S., "The Express Tribune", 22 March, 2017, [Online]. Available: https://tribune.com.pk/story/1362083/worldwater-day-less-8-urban-waste-water-treatedpakistan-says-report/.

[5] Mazaheri R., Orumieh H.R., "Efficiency of Stabilization Ponds Under Different Climatic Conditions in Iran", Indian Journal of Fundamental and Applied Life Sciences, Vol. 5, pp. 794-805, 2015.

[6] Hadi R., Salmani E.R., Alipour M.R., Alidadi H., Peiravi R., "Wastewater Treatment Efficiency in Stabilization Ponds, Olang Treatment Plant, Mashhad", Iranian Journal of Health, Safety \& Environment, Vol. 2, No. 1, , pp. 217-223., 2013,

[7] A\&A., "WPCF, Standard Methods for the Examination of Water and Wastewater", Sien Diego, PubMart, 2005.

[8] Jaji M.O., Bamgbose O., Odukoya O.O., Arowolo T.A., "Water Quality Assessment of Ogun River, South West Nigeria", Envoronmental Monitoring and Assessment, Vol. 133, pp. 473-482, October 2007.

[9] McCulloch W.L., Goodfellow W.L., Black J.A., "Characterization, Identification and Confirmation of Total Dissolved Solids as Effluent Toxicants". In Gorsuch J., Dwyer F., Ingersoll C., La T.P. (Eds.): Environmental Toxicology and Risk Assessment, Vol. 2, pp. 213-227, ASTM International, 1993.

[10] Gratiziou M.I., Chalastsi M., "Sludge Accumulation and Charecteristics in a Wastewater Stabilization Pond Systems in
Vamvakofito - North Greece", Proceedings of 14th International Conference on Environmental Science and Technology, Rhodes, Greece, 3-5 September, 2015.

[11] Divine A., "Assessing the Efficiency of the Akosombo Wastewater Stabilization Pond", Kwame Nkrumah University of Science \& Technology, Kumasi, Akosombo, August, 2011.

[12] Hodgson I.O.A., "Treatment of Domestic Sewage at Akuse (Ghana)", Water Research Institute, pp. 413-415, Accra, Ghana, July, 2000.

[13] Jill S., Baron N., LeRoy P., Paul L., Angermeier C.N., Dahm P.H.G., Nelson G.H., Robert B.J., Carol A.J., Brian D.R., Alan D.S., "Sustaining Healthy Freshwater Ecosystems", Issues in Ecology, pp. 1-16, 2003.

[14] Governament of Pakistan, "Extra Ordinary Issue", 12th August 2016. [Online]. Available at:

http://epd.punjab.gov.pk/system/files/Punjab $\% 20$ Environmental\%20Quality\%20Standard s\%20for\%20Muncipal\%20And\%20Liquid\% 20Industrial\%20Effluents\%20final.pdf.

[Last Accessed on 1st January 2018].

[15] Barjenbrach M.A.C.E., “A Performance Review of Small German WSPs Identifying Improvement", Water Science Technology, Vol. 51, No. 12, , pp. 43-49, 2005.

[16] Hashmi I., Khan Z.D., Farooq S., "Physiochemical Characterization of Wastewater in Pharang Drain, Faisalabad", Institute of Environmental Sciences and Engineering, NUST Journal of Sciences, Vol. 4, pp. 1-9, 2011. 